\title{
Comparison of Certain Road Accident Indicators in Poland and Selected European Countries
}

\author{
Jerzy Kisilowski ${ }^{1}$, Jaroslaw Zalewski ${ }^{2, *}$ \\ ${ }^{1}$ Kazimierz Pulski University of technology and Humanities, Faculty of Transport and Electrical Engineering, Malczewskiego \\ 29, 26-600 Radom, Poland \\ ${ }^{2}$ Warsaw University of Technology, Faculty of Administration and Social Sciences, Pl. Politechniki 1, 00-661 Warsaw, Poland \\ *Corresponding Author: jarek.zalew@gmail.com
}

Copyright (C) 2014 Horizon Research Publishing All rights reserved.

\begin{abstract}
The article discusses selected aspects of the analysis on road accidents data and the possibility of their use in order to create a background for further, more exhaustive study of specific problems of road safety. These problems may result from such analyzes by their breakdown through specific comparisons and drawing appropriate conclusions. Attention was paid to the manner of data presentation and important problem of their systematic collection. In this paper the results of particular analyses as well as selected aspects concerning the causes of road accidents are discussed. Attention was paid to the possibilities of conducting detailed analysis on this research area. Occurrence of road accidents does not have to be connected with relationships directly between motor vehicles, and it seems obvious that the influence of environment should be included. Also an important issue of systematic and consistent data collection about accidents is mentioned.
\end{abstract}

Keywords Road Accidents, Road Traffic Safety, Fatalities, Injuries, Infrastructure

\section{Introduction}

In the paper selected problems are undertaken concerning the way of presentation and analysis of data on road traffic accidents as a comparison between Poland and selected European countries. Such an approach is presented, which, except for pure data, allows developing information (indicators) on selected issues of road traffic accidents, draw conclusions and run analysis on the basis of trends, particularly when presented data are incomplete.

For the comparison of accident indicators data from Czech Republic, France, Germany, Poland and the United Kingdom were selected for the period 2002 to 2012. Data sets were derived from the accountancy system of incidents and accidents (SEWiK) in Poland [1] as well as the UN database [2]. Some parts of the United Nations database are incomplete; hence not all indicators are presented for the full period of the given 11 years. Data in the United Nations are sometimes little corrected, in particular at the beginning of each year. Data sets presented for purposes of this paper are up to date for January 2013.

In order to complete some deficiencies, certain statistical yearbooks of the German statistical office DESTATIS-Statistisches Bundesamt [3], the World Development Indicators (WDI) by the World Bank [4] and data from Czech Statistical Office (5) were used. Lack of data are marked with "_" in every table.

It should be highlighted that the approach to analysing road traffic accidents proposed by the author is only a part of a wider analysis [9], [10] and may complement or compose a background for broader considerations.

In order to ensure data representativeness the indicators were used, through which not only selected data can be compared in relative values ([6], [7], [8]), but above all the trends resulting from changes in these values can be analysed. In addition, the aim of the paper is to present the analysis results based on assessment of these trends, when not all data are complete. The completeness of data is determined by their availability and complexity of the analysed issues. Unfortunately, using publicly available databases mentioned above it was not possible to complete the full data, thus the interpretation of the obtained resources results mainly from the trends in changes of the observed indicators.

Final conclusions are not arbitrarily imposed points of reference as directions for further research to improve road safety, but only a desire to focus on certain essential aspects which may be used in any further action or bear evidence of the amendments made.

\section{Comparison of the Selected Indicators}


Statistical data are often used as a factor or background justifying undertaking certain research. They may be presented in two ways. The first one is presentation of data in an unprocessed form. This method enables nothing more but only displaying incomplete information, for which no comparisons can be made, especially between different countries. In table 1 and 2 data concerning the number of fatalities and injuries in road accidents in selected European countries are presented. The period from 2002 to 2012 is included and data are presented in absolute values. Such attempt was presented before in [6], [7] and [8].

Table 1. The number of fatalities in the selected countries between 2002 and 2012 .

\begin{tabular}{|c|c|c|c|c|c|}
\hline & \multicolumn{5}{|c|}{ Fatalities } \\
\hline Year & $\begin{array}{c}\text { Czech } \\
\text { Republic }\end{array}$ & France & Germany & Poland & $\begin{array}{c}\text { Great } \\
\text { Britain }\end{array}$ \\
\hline 2002 & 1430 & 7655 & 6842 & 5827 & 3581 \\
\hline 2003 & 1447 & 6058 & 6613 & 5640 & 3658 \\
\hline 2004 & 1382 & 5530 & 5842 & 5712 & 3368 \\
\hline 2005 & 1286 & 5318 & 5361 & 5444 & 3336 \\
\hline 2006 & 1063 & 4709 & 5091 & 5243 & 3298 \\
\hline 2007 & 1221 & 4620 & 4949 & 5583 & 3059 \\
\hline 2008 & 1076 & 4275 & 4477 & 5437 & 2645 \\
\hline 2009 & 901 & 4273 & 4152 & 4572 & 2337 \\
\hline 2010 & 802 & 3992 & 3648 & 3907 & 1905 \\
\hline 2011 & 773 & 3963 & 4009 & 4189 & - \\
\hline 2012 & - & - & - & 3557 & - \\
\hline
\end{tabular}

Table 2. The number of injuries in the selected countries between 2002 and 2012.

\begin{tabular}{|c|c|c|c|c|c|}
\hline & \multicolumn{5}{|c|}{ Injuries } \\
\hline Year & $\begin{array}{c}\text { Czech } \\
\text { Republic }\end{array}$ & France & Germany & Poland & $\begin{array}{c}\text { Great } \\
\text { Britain }\end{array}$ \\
\hline 2002 & 34389 & 137427 & 476404 & 67502 & 310938 \\
\hline 2003 & 35438 & 115602 & 462170 & 63905 & 297274 \\
\hline 2004 & 34254 & 108429 & 440109 & 64667 & 286979 \\
\hline 2005 & 32211 & 108429 & 433430 & 61196 & 275840 \\
\hline 2006 & 28114 & 108076 & 422322 & 59121 & 264288 \\
\hline 2007 & 29191 & 102125 & 431419 & 63224 & 254157 \\
\hline 2008 & 28501 & 103201 & 409047 & 62097 & 237811 \\
\hline 2009 & 27244 & 95207 & 397671 & 56045 & 229576 \\
\hline 2010 & 24384 & 84461 & 371170 & 48952 & 217605 \\
\hline 2011 & 25611 & - & - & 49501 & - \\
\hline 2012 & - & - & - & 45637 & - \\
\hline
\end{tabular}

In order to prepare an overall assessment of road traffic safety in the compared countries on the basis of so presented statements, a conclusion can be made that both in terms of fatalities and injuries, Czech Republic is characterised by the highest level of safety, whereas Poland performs better in these comparisons than Germany and France. However, such information is incomplete, and in addition cannot be verified without additional data.

Another approach is the analysis of trends in changes of the number of fatalities and injuries in road accidents in all five countries. Results show that in each compared country there is a declining trend, while in such approach values for separate years are not as important as the difference between the initial and the final one. Therefore the greatest decrease in the number of fatalities was reported in France, because there were about 3700 fatalities less in 2011 than in 2002. In terms of the number of injured in road accidents it can be ascertained that in the given decade the main decrease occurred in Germany and the United Kingdom.

The question that rises is whether data presented in such a way are representative, i.e. whether on the basis of them certain comparative analyses can be made. No reply seems to be unambiguous, particularly when taking into account the additional factors such as the number of road vehicles in each country, overall length of the road network, nature of the accidents (type and location of the collision), number of inhabitants, etc. In order to run such analysis more complete, certain factors should be taken into account, which can on one hand enable the comparisons and, on the other, explain the occurred juncture.

Table 3. The number of road accidents in the selected countries between 2002 and 2012.

\begin{tabular}{|c|c|c|c|c|c|}
\hline & \multicolumn{5}{|c|}{ Number of accidents } \\
\hline Year & $\begin{array}{c}\text { Czech } \\
\text { Republic }\end{array}$ & France & Germany & Poland & $\begin{array}{c}\text { Great } \\
\text { Britain }\end{array}$ \\
\hline 2002 & 26586 & 105470 & 362054 & 53558 & 228535 \\
\hline 2003 & 27320 & 90220 & 354534 & 51076 & 220079 \\
\hline 2004 & 26516 & 85390 & 339308 & 51068 & 213043 \\
\hline 2005 & 25239 & 84525 & 336618 & 48100 & 203682 \\
\hline 2006 & 22115 & 80309 & 327984 & 46875 & 194789 \\
\hline 2007 & 23060 & 81272 & 335845 & 49536 & 188105 \\
\hline 2008 & 22481 & 74487 & 320614 & 49054 & 176814 \\
\hline 2009 & 21706 & 72315 & 310806 & 44195 & 169805 \\
\hline 2010 & 19676 & 67288 & 288297 & 38832 & 154414 \\
\hline 2011 & - & 65024 & 306266 & 40065 & - \\
\hline 2012 & - & - & - & 36927 & - \\
\hline
\end{tabular}

In table 3 the number of road accidents in Czech Republic, France, Germany, Poland and the United Kingdom in the years 2002 to 2012 is presented. It is discernible that the greatest decrease in the number of road accidents took place in Germany (about 90000) and in Great Britain (by around 80000).

After analysis of data from the tables 1 to 3 , first and foremost trends in their changes, it appears that the first impression concerning road traffic safety in Czech Republic was not appropriate, as evidenced by a large number of injuries in the relatively small number of accidents as compared to four other countries. But because it is insufficient to compare separate data for each year and between different countries in absolute values, more detailed analysis was prepared.

Using additional data which form the background of changes and comparative plane two additional tables were prepared. In table 4 the number of road vehicles in the 
selected countries from 2002 to 2012 is shown. It should be noted that only in Czech Republic in the given period there were around 3 times less vehicles than in Poland. However in France and the United Kingdom there were more than two, while in Germany over three times more vehicles than in Poland. In relation to this fact the comparison of the absolute values between the given countries and for concrete years raises wrong conclusions concerning the actual juncture. Such information cannot therefore be the basis of comparative analyses, because it contains the data not related to the common datum plane (e.g. the number of vehicles).

Table 4. The number of road vehicles in the selected countries between 2002 and 2012.

\begin{tabular}{|c|c|c|c|c|c|}
\hline & \multicolumn{5}{|c|}{ Number of vehicles } \\
\hline Year & $\begin{array}{c}\text { Czech } \\
\text { Republic }\end{array}$ & France & Germany & Poland & Great Britain \\
\hline 2002 & 3998696 & 34808708 & 47463269 & 15525733 & 29976693 \\
\hline 2003 & 4092385 & 35228622 & 47797096 & 15899195 & 30504851 \\
\hline 2004 & 4231701 & 35393620 & 48219014 & 16701072 & 31607029 \\
\hline 2005 & 4396641 & 35631525 & 48939105 & 16815923 & 32170344 \\
\hline 2006 & 4620235 & 36164754 & 49457882 & 18035047 & 31344793 \\
\hline 2007 & 4855247 & 36619045 & 43762067 & 19472000 & 31961051 \\
\hline 2008 & 5050787 & 36517187 & 43852088 & 21336913 & 32324715 \\
\hline 2009 & 5056710 & 37101560 & 44370443 & 22024697 & 32087899 \\
\hline 2010 & 5368068 & 37625443 & 44997890 & 23037149 & 32270122 \\
\hline 2011 & 6414559 & - & 45716613 & 24189370 & - \\
\hline 2012 & - & - & - & - & - \\
\hline
\end{tabular}

When possessing the additional data, the question can be answered of how the increase in density of road vehicles contributed to occurrence of road traffic accidents as well as the number of fatalities and injuries.

One of the indicators enabling comparisons can be the number of accidents, fatalities or injuries in relation to 100 000 vehicles (2.1) depending on the purpose of comparison.

$$
A_{i}=A_{t} \cdot \frac{100000}{V}, D_{i}=D_{t} \cdot \frac{100000}{V}, I_{i}=I_{t} \cdot \frac{100000}{V}
$$

where:

- $V$ - the number of road vehicles in every selected country in the given year,

- $A_{i}$ - the number of accidents per 100000 vehicles in the given year,

- $A_{t}$ - the total number of accidents in every selected country in the given year,

- $D_{i}$ - the number of fatalities per 100000 vehicles in the given year,

- $D_{t}$ - the total number of fatalities in every selected country in the given year,

- $I_{i}$ - the number of injuries per 100000 vehicles in the given year,
- $I_{t}$ - the total number of injuries in every selected country in the given year.

In the tables $5-7$ the number of accidents, fatalities and injuries in relation to 100000 vehicles in the years from 2002 to 2012 is shown, on the basis of formulas (2.1). From the comparison it can be seen that with much more accidents in Czech Republic, Germany and Great Britain (table 5), and comparable number of accidents in France in relation to 100000 vehicles, the largest number of fatalities for the concerned period occurred in Poland. Moreover, in Germany and Great Britain, despite the large amount of vehicles, the number of fatalities per 100000 vehicles had been smallest every year (table 6).

When examining the trends of these changes it can be seen that, in terms of both accidents and fatalities per 100000 vehicles, the largest decrease of these indicators occurred in Czech Republic, Poland and the United Kingdom.

In a matter of injured per 100000 vehicles the most beneficial situation had year by year been in France and Poland (table 7), while the greatest absolute number of injured had been in Germany and the United Kingdom. When analysing the trends it can be seen that the greatest decrease in the number of the injured throughout 10 years occurred in Czech Republic and the United Kingdom.

Two different approaches give different results. However, when comparing data in relative values it is necessary to relate them to the conditions for which these data were collected. For example, the high number of injuries in Germany can not be an evidence of the poor road safety condition, because, year by year, the number of vehicles had been the highest among the five countries compared. In addition, taking into account the area of Germany equal to approximately $357000 \mathrm{~km}^{2}$ and comparing it, e.g. with France (more than $640000 \mathrm{~km}^{2}$ ) the greatest car density may be assumed to had been in Germany (from among five selected countries).

Table 5. The number of accidents per 100000 vehicles in the selected countries between 2002 and 2012 .

\begin{tabular}{|c|c|c|c|c|c|}
\hline & \multicolumn{5}{|c|}{ Accidents per 100000 vehicles } \\
\hline Year & $\begin{array}{c}\text { Czech } \\
\text { Republic }\end{array}$ & France & Germany & Poland & $\begin{array}{c}\text { Great } \\
\text { Britain }\end{array}$ \\
\hline 2002 & 664,87 & 303,00 & 762,81 & 344,97 & 762,38 \\
\hline 2003 & 667,58 & 256,10 & 741,75 & 321,26 & 721,46 \\
\hline 2004 & 626,60 & 241,26 & 703,68 & 305,78 & 674,04 \\
\hline 2005 & 574,05 & 237,22 & 687,83 & 286,04 & 633,14 \\
\hline 2006 & 478,66 & 222,06 & 663,16 & 259,92 & 621,44 \\
\hline 2007 & 474,95 & 223,34 & 767,43 & 254,40 & 588,54 \\
\hline 2008 & 445,10 & 204,69 & 731,13 & 229,90 & 546,99 \\
\hline 2009 & 429,25 & 198,62 & 700,47 & 200,67 & 529,18 \\
\hline 2010 & 366,53 & 178,83 & 640,69 & 168,56 & 496,06 \\
\hline 2011 & - & - & 669,92 & 165,63 & - \\
\hline 2012 & - & - & - & - & - \\
\hline
\end{tabular}


Table 6. The number of fatalities per 100000 vehicles in the selected countries between 2002 and 2012 .

\begin{tabular}{|c|c|c|c|c|c|}
\hline & \multicolumn{5}{|c|}{ Fatalities per 100000 vehicles } \\
\hline Year & $\begin{array}{c}\text { Czech } \\
\text { Republic }\end{array}$ & France & Germany & Poland & $\begin{array}{c}\text { Great } \\
\text { Britain }\end{array}$ \\
\hline 2002 & 35,76 & 21,99 & 14,42 & 37,53 & 11,95 \\
\hline 2003 & 35,36 & 17,20 & 13,84 & 35,47 & 11,99 \\
\hline 2004 & 32,66 & 15,62 & 12,12 & 34,20 & 10,66 \\
\hline 2005 & 29,25 & 14,92 & 10,95 & 32,37 & 10,37 \\
\hline 2006 & 23,01 & 13,02 & 10,29 & 29,07 & 10,52 \\
\hline 2007 & 25,15 & 12,70 & 11,31 & 28,67 & 9,57 \\
\hline 2008 & 21,30 & 11,75 & 10,21 & 25,48 & 8,18 \\
\hline 2009 & 17,82 & 11,73 & 9,35 & 20,76 & 7,28 \\
\hline 2010 & 14,94 & 10,6 & 8,10 & 16,96 & 5,90 \\
\hline 2011 & 12,05 & - & 8,76 & 17,31 & - \\
\hline 2012 & - & - & - & - & - \\
\hline
\end{tabular}

Table 7. The number of injuries per 100000 vehicles in the selected countries between 2002 and 2012

\begin{tabular}{|c|c|c|c|c|c|}
\hline \multirow{2}{*}{ Year } & \multicolumn{5}{|c|}{ Injuries per 100000 vehicles } \\
\cline { 2 - 6 } & $\begin{array}{c}\text { Czech } \\
\text { Republic }\end{array}$ & France & Germany & Poland & $\begin{array}{c}\text { Great } \\
\text { Britain }\end{array}$ \\
\hline 2002 & 860,01 & 394,81 & 1003,73 & 434,75 & 1037,27 \\
\hline 2003 & 865,95 & 328,15 & 96,69 & 401,91 & 974,51 \\
\hline 2004 & 809,46 & 306,35 & 912,73 & 387,17 & 907,96 \\
\hline 2005 & 732,63 & 304,31 & 885,65 & 363,89 & 857,44 \\
\hline 2006 & 608,50 & 298,84 & 853,90 & 327,82 & 843,16 \\
\hline 2007 & 601,23 & 280,64 & 985,83 & 324,69 & 795,21 \\
\hline 2008 & 564,29 & 283,60 & 932,79 & 291,03 & 735,69 \\
\hline 2009 & 556,58 & 261,50 & 905,60 & 254,47 & 722,74 \\
\hline 2010 & 454,24 & 224,47 & 824,86 & 212,49 & 674,32 \\
\hline 2011 & 399,26 & - & - & 204,64 & - \\
\hline 2012 & - & - & - & - & - \\
\hline
\end{tabular}

When analysing the trends of changes in the accident indicators rates (relative values) it is possible, without a complete data set, to notice the differences in their values over the years and thus draw conclusions regarding the changes in a specified period of time. Taking into account e.g. the number of fatalities per 100000 vehicles (table 6) it can be assessed, that the greatest progress in eliminating fatal accidents took place in Poland and Czech Republic (the decrease of more than twice). It is important that at the same period the number of road vehicles had been constantly increasing year by year (table 4 ) and had nearly doubled for both countries.

Analysis presented above allows conclusion that in order to achieve a low number of fatalities in road accidents certain activities, at least partially, can be directed towards improving the number of injuries. Of course such status is not achieved deliberately, and may result rather from the nature of the carried out activities. On one hand increasingly better and safer structures of road vehicles, on the other appropriate traffic control might enable optimisation of its fluency aimed at reducing the number of fatalities. Road network modernisations and development of infrastructure (e.g. motorways with roads separated by barriers) might increase the number of injured, because it may lead to reduction of front and side impact collisions, however the number of rear collisions may increase (e.g. multiple collisions).

An important aspect of infrastructure modernisation as well is the elimination of using the same roads by different groups of users, as referred to in the further part of the paper.

In table 8 the number of inhabitants for each compared country from 2002 to 2012 is shown, which gave the opportunity to present an indicator - the number road vehicles per 1 million inhabitants (table 9). This dataset shows that over the considered years the number of vehicles along with the low demographic increment in Germany, France and the United Kingdom the density of vehicles remained at the same level. Demographic growth in Czech Republic was also low, while the density of vehicles had increased significantly, whereas in Poland along with the low decrease, significant growth in density of vehicles can be noticed.

Table 8. The number of inhabitants in the selected countries between 2002 and 2012.

\begin{tabular}{|c|c|c|c|c|c|}
\hline \multirow{2}{*}{ Year } & \multicolumn{5}{|c|}{ Number of inhabitants } \\
\cline { 2 - 6 } & $\begin{array}{c}\text { Czech } \\
\text { Republic }\end{array}$ & France & Germany & Poland & $\begin{array}{c}\text { Great } \\
\text { Britain }\end{array}$ \\
\hline 2002 & 10204852 & 61644062 & 82488494 & 38230364 & 59325809 \\
\hline 2003 & 10207362 & 62078164 & 82534176 & 38204570 & 59566258 \\
\hline 2004 & 10216016 & 62532556 & 82516260 & 38182222 & 59867866 \\
\hline 2005 & 10235828 & 63001252 & 82469422 & 38165445 & 60224306 \\
\hline 2006 & 10269134 & 63437350 & 82376450 & 38141267 & 60595632 \\
\hline 2007 & 10334160 & 63826129 & 82266372 & 38120560 & 60986648 \\
\hline 2008 & 10424336 & 64178710 & 82110096 & 38125758 & 61393521 \\
\hline 2009 & 10487177 & 64522361 & 81902306 & 38151602 & 61811026 \\
\hline 2010 & 10496772 & 64871454 & 81776929 & 38348597 & 62262787 \\
\hline 2011 & 10496088 & 65223162 & 81797672 & 38534156 & 62744081 \\
\hline 2012 & - & - & - & - & - \\
\hline
\end{tabular}

Table 9. The number of vehicles per 1 million inhabitants in the selected countries between 2002 and 2012 .

\begin{tabular}{|c|c|c|c|c|c|}
\hline \multirow{2}{*}{ Year } & \multicolumn{5}{|c|}{ Road vehicles per 1 million inhabitants } \\
\cline { 2 - 6 } & $\begin{array}{c}\text { Czech } \\
\text { Republic }\end{array}$ & France & Germany & Poland & $\begin{array}{c}\text { Great } \\
\text { Britain }\end{array}$ \\
\hline 2002 & 391842,6 & 564672,5 & 575392,6 & 406110,0 & 505289,2 \\
\hline 2003 & 400924,8 & 567488,1 & 579118,8 & 416159,5 & 512116,3 \\
\hline 2004 & 414222,2 & 566003,1 & 584357,7 & 437404,4 & 527946,5 \\
\hline 2005 & 429534,5 & 565568,5 & 593421,2 & 440606,0 & 534175,4 \\
\hline 2006 & 449914,8 & 570086,1 & 600388,6 & 472848,7 & 517278,1 \\
\hline 2007 & 469825,0 & 573731,3 & 531955,7 & 510800,5 & 524066,4 \\
\hline 2008 & 484518,8 & 568992,2 & 534064,5 & 559645,6 & 526516,7 \\
\hline 2009 & 482180,3 & 575018,6 & 541748,4 & 577294,2 & 519129,0 \\
\hline 2010 & 511401,8 & 580000,0 & 550251,6 & 600729,9 & 518289,1 \\
\hline 2011 & 611138,1 & - & 558898,7 & 627738,4 & - \\
\hline 2012 & - & - & - & - & - \\
\hline
\end{tabular}

Information about fatalities or injuries in road accidents 
can also be analysed in relation to the number of accidents. In connection with this the number of fatalities and injuries in relation to 1000 accidents for each of the selected years are presented. Indicator describing this dataset was calculated with the use of formulas (2.2).

$$
D_{i}=D_{t} \cdot \frac{1000}{A_{i}}, \quad I_{i}=I_{t} \cdot \frac{1000}{A_{i}}
$$

where:

- $A_{i}$ - the number of accidents in the selected country for each of the analysed years,

- $D_{i}$ - the number of fatalities per 1000 accidents in the selected country for each of the analysed years,

- $D_{t}$ - the total number of fatalities in the selected country for each of the analysed years,

- $I_{i}$ - the number of injuries per 1000 accidents in the selected country for each of the analysed years,

- $I_{t}$ - the total number of injuries in the selected country for each of the analysed years.

Table 10. The number of fatalities per 1000 road accidents between 2002 and 2012 in the selected countries.

\begin{tabular}{|c|c|c|c|c|c|}
\hline \multirow{2}{*}{ Year } & \multicolumn{5}{|c|}{ Fatalities per 1000 accidents } \\
\cline { 2 - 6 } & $\begin{array}{c}\text { Czech } \\
\text { Republic }\end{array}$ & France & Germany & Poland & $\begin{array}{c}\text { Great } \\
\text { Britain }\end{array}$ \\
\hline 2002 & 53,8 & 72,6 & 18,9 & 108,8 & 15,7 \\
\hline 2003 & 53,0 & 67,1 & 18,7 & 110,4 & 16,6 \\
\hline 2004 & 52,1 & 64,8 & 17,2 & 111,9 & 15,8 \\
\hline 2005 & 51,0 & 62,9 & 15,9 & 113,2 & 16,4 \\
\hline 2006 & 48,1 & 58,6 & 15,5 & 111,9 & 16,9 \\
\hline 2007 & 52,9 & 56,8 & 14,7 & 112,7 & 16,3 \\
\hline 2008 & 47,9 & 57,4 & 14,0 & 110,8 & 15,0 \\
\hline 2009 & 41,5 & 59,1 & 13,4 & 103,5 & 13,8 \\
\hline 2010 & 40,8 & 59,3 & 12,7 & 100,6 & 12,3 \\
\hline 2011 & - & 60,9 & 13,1 & 104,6 & - \\
\hline 2012 & - & - & - & 96,3 & - \\
\hline
\end{tabular}

In table 10 the number of fatalities, whereas in table 11 the number of injuries in relation to 1000 accidents is presented for the considered period. Supposing every year only in Czech Republic there were less accidents than in Poland (see table 3), that at the beginning of the period the number of fatalities in 1000 accidents was the highest in Poland (over two times more than in Czech Republic, almost twice as much as in France and almost six times more than in Germany and Great Britain). However, when examining the trend of this indicator, the largest decline of its value can be observed in Poland, where the difference between the beginning and the end of the period is more than 20 fatalities less per 1000 accidents. In any other compared countries so significant decrease had not taken place. Noticeable differences are in France (about 9 fatalities less) and in Czech Republic (14).

The number of injuries per 1000 accidents at the beginning of the selected period was in all countries similar and oscillated around 1300. It is important that a similar number of injuries had been noticed in the countries with different number of road accidents. The trend, however, shows that the greatest decrease in the values of this indicator until the year 2010 took place in Czech Republic and Germany. In France weak fluctuations can be noted with a small tendency of decrease, in Poland the trend had shown stability with the average value around 1265 injured in 1000 accidents, while the UK little growth occurred. But the figures in the years 2011 - 2012 show that in Poland the number of injuries per 1000 accidents had been reduced by 25 people in relation to the year 2010 . Incomplete data have prevented broader analysis, but despite that the annual decrease in the number of road accidents in the rest of the selected countries can be expected, as well as the fact that it had been as significant as in Poland, except maybe for Czech Republic.

Table 11. The number of injuries prf 1000 road accidents in the selected countries between 2002 and 2012 .

\begin{tabular}{|c|c|c|c|c|c|}
\hline \multirow{2}{*}{ Year } & \multicolumn{5}{|c|}{ Injuries per 1000 accidents } \\
\cline { 2 - 6 } & $\begin{array}{c}\text { Czech } \\
\text { Republic }\end{array}$ & France & Germany & Poland & $\begin{array}{c}\text { Great } \\
\text { Britain }\end{array}$ \\
\hline 2002 & 1293,5 & 1303,0 & 1315,8 & 1260,4 & 1360,6 \\
\hline 2003 & 1297,1 & 1281,3 & 1303,6 & 1251,2 & 1350,8 \\
\hline 2004 & 1291,8 & 1269,8 & 1297,1 & 1266,3 & 1347,0 \\
\hline 2005 & 1276,2 & 1282,8 & 1287,6 & 1272,3 & 1354,3 \\
\hline 2006 & 1271,3 & 1345,8 & 1287,6 & 1261,2 & 1356,8 \\
\hline 2007 & 1265,9 & 1256,6 & 1284,6 & 1276,3 & 1351,1 \\
\hline 2008 & 1267,8 & 1385,5 & 1275,8 & 1265,9 & 1345,0 \\
\hline 2009 & 1255,1 & 1316,6 & 1279,5 & 1268,1 & 1352,0 \\
\hline 2010 & 1239,3 & 1255,2 & 1287,5 & 1260,6 & 1409,2 \\
\hline 2011 & - & - & - & 1235,5 & - \\
\hline 2012 & - & - & - & 1235,9 & - \\
\hline
\end{tabular}

Having such prepared indicators at disposal not only comparisons can be made, but also trends of these indicators identified (6), i.e. forecasting of their changes in the close future, under certain road traffic conditions, number of vehicles and changes in road infrastructure. Example of such analysis is presented in the form graph (figure 1) showing the dynamics of changes in the number of fatalities in 1000 accidents from the point of view of trend analysis.

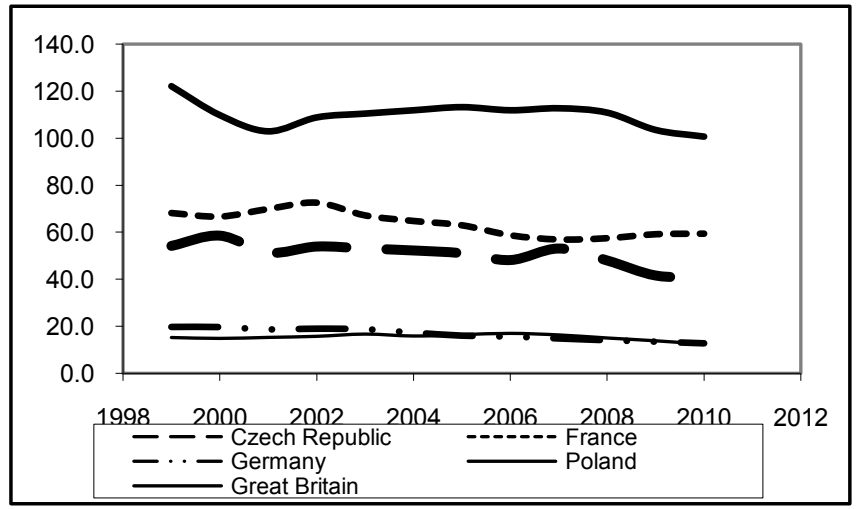

Figure 1. Dynamics of the change in the number of fatalities per 1000 road accidents for the compared countries. 
Analysis of the possible influence of changes in road infrastructure on the causes of accidents was the subject of [6] and [7] for the period between 1995 and 2008. In these papers hypotheses were raised concerning reduction of the number of fatalities in road accidents by removing different types of users off the same road. Those are confirmed by the results of studies presented above for the subsequent period.

The above considerations do not mean, however, that the data presented in absolute terms are in general unnecessary. Presenting them with a suitable interpretation may comprise a justification for the drawn conclusions.

Table 12. The number of accidents in the selected countries from 2002 to 2012 with division into accidents on motorways, in and outside built-up areas.

\begin{tabular}{|c|c|c|c|c|c|c|c|c|c|c|c|c|c|}
\hline Year & 2002 & 2003 & 2004 & 2005 & 2006 & 2007 & 2008 & 2009 & 2010 & 2011 & 2012 \\
\hline \multicolumn{10}{|c|}{ Accidents on motorways } \\
\hline $\begin{array}{c}\text { Czech } \\
\text { Republic }\end{array}$ & 442 & 444 & 455 & 450 & 449 & 481 & 447 & 412 & 432 & - & - \\
\hline France & 7596 & 6161 & 5285 & 5160 & 5094 & 5327 & 4703 & 4368 & 4756 & 4139 & - \\
\hline Germany & 24625 & 22646 & 21458 & 20943 & 20434 & 20466 & 18269 & 18394 & 18829 & 18290 & - \\
\hline Poland & 238 & 219 & 215 & 228 & b.d. & 551 & 283 & 237 & 274 & 232 & - \\
\hline $\begin{array}{c}\text { Great } \\
\text { Britain }\end{array}$ & 8942 & 8746 & 9072 & 8718 & 8506 & 8116 & 7249 & - & 6500 & - & - \\
\hline
\end{tabular}

Accidents in built-up areas

\begin{tabular}{|c|c|c|c|c|c|c|c|c|c|c|c|}
\hline $\begin{array}{c}\text { Czech } \\
\text { Republic }\end{array}$ & 16901 & 16936 & 16517 & 15636 & 13551 & 13719 & 13443 & 12987 & 12005 & - & - \\
\hline France & 68683 & 60162 & 57790 & 58676 & 54981 & 56049 & 52057 & 50864 & 46846 & 45377 & - \\
\hline Germany & 233865 & 230521 & 223314 & 225875 & 221504 & 228717 & 221306 & 213361 & 195833 & 210427 & - \\
\hline Poland & 38652 & 36912 & 36694 & 34234 & b.d. & 42768 & 34881 & 31599 & 27836 & 29144 & - \\
\hline $\begin{array}{c}\text { Great } \\
\text { Britain }\end{array}$ & 161236 & 154995 & 148377 & 91737 & 87843 & 86473 & 128104 & - & 114238 & - & - \\
\hline
\end{tabular}

\begin{tabular}{|c|c|c|c|c|c|c|c|c|c|c|c|}
\hline \multicolumn{10}{|c|}{ Accidents outside built-up areas } \\
\hline $\begin{array}{c}\text { Czech } \\
\text { Republic }\end{array}$ & 9243 & 9940 & 9544 & 9153 & 8115 & 8860 & 8591 & 8307 & 7239 & - & - \\
\hline France & 29191 & 23897 & 22315 & 20688 & 20234 & 19896 & 17727 & 17083 & 15686 & 15508 & - \\
\hline Germany & 103564 & 101367 & 94538 & 89801 & 86046 & 86662 & 81039 & 79051 & 73635 & 77549 & - \\
\hline Poland & 14907 & 14166 & 14375 & 13636 & b.d. & 19905 & 13892 & 12360 & 10722 & 10689 & - \\
\hline $\begin{array}{c}\text { Great } \\
\text { Britain }\end{array}$ & 51573 & 50289 & 49961 & 43201 & 42149 & 40232 & 41330 & - & 33676 & - & - \\
\hline
\end{tabular}

Table 13. Total length of motorways and other road types in the selected countries between 2002 and 2012.

\begin{tabular}{|c|c|c|c|c|c|c|c|c|c|c|c|c|}
\hline Year & \multirow{12}{*}{ 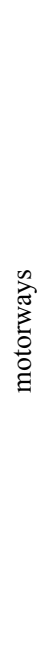 } & $\begin{array}{c}\text { Czech } \\
\text { Republic }\end{array}$ & France & Germany & Poland & $\begin{array}{c}\text { Great } \\
\text { Britain }\end{array}$ & \multirow{12}{*}{ 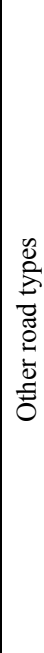 } & $\begin{array}{c}\text { Czech } \\
\text { Republic }\end{array}$ & France & Germany & Poland & $\begin{array}{c}\text { Great } \\
\text { Britain }\end{array}$ \\
\hline 2002 & & 518 & 10223 & 12037 & 405 & 3611 & & 127204 & 984131 & - & 377839 & 416469 \\
\hline 2003 & & 518 & 10379 & 12044 & 405 & 3611 & & 127856 & 987622 & - & 382789 & 417185 \\
\hline 2004 & & 546 & 10486 & 12174 & 552 & 3657 & & 127880 & 992000 & 644467 & 384956 & 412582 \\
\hline 2005 & & 564 & 10800 & 12363 & 552 & 3629 & & 127872 & 998308 & 644480 & 386963 & 409309 \\
\hline 2006 & & 633 & 10848 & 12531 & 663 & 3665 & & 129871 & 1003177 & 644359 & 388115 & 415764 \\
\hline 2007 & & 657 & 10958 & 12594 & 663 & 3669 & & 129846 & 1016225 & 644181 & 388553 & 416330 \\
\hline 2008 & & 691 & 11042 & 12645 & 765 & 3673 & & 129882 & 1016749 & 643999 & 388813 & 415961 \\
\hline 2009 & & 729 & 11163 & 12813 & 849 & 3674 & & 129909 & 1030010 & 644969 & 389604 & 416001 \\
\hline 2010 & & 734 & 11392 & 12819 & 857 & 3673 & & 129937 & 1038725 & - & 411622 & 415953 \\
\hline 2011 & & - & 11412 & 12845 & 1070 & 3686 & & - & 1041803 & - & 412264 & 416067 \\
\hline 2012 & & - & - & - & - & - & & - & b.d. & - & - & - \\
\hline
\end{tabular}


Table 14. The number of accidents on dry road surface and other road conditions between 2002 and 2008 .

\begin{tabular}{|c|c|c|c|c|c|c|c|c|c|c|}
\hline \multirow{2}{*}{ Year } & \multicolumn{5}{|c|}{ Dry road surface } & \multicolumn{5}{c|}{ Other conditions (wet, icy, etc.) } \\
\cline { 2 - 13 } & $\begin{array}{c}\text { Czech } \\
\text { Republic }\end{array}$ & France & Germany & Poland & $\begin{array}{c}\text { Great } \\
\text { Britain }\end{array}$ & $\begin{array}{c}\text { Czech } \\
\text { Republic }\end{array}$ & France & Germany & Poland & $\begin{array}{c}\text { Great } \\
\text { Britain }\end{array}$ \\
\hline 2002 & 18071 & 83142 & 244276 & 35850 & 140096 & 8515 & 22328 & 117778 & 17627 & 81655 \\
\hline 2003 & 20082 & 75546 & 263049 & 34722 & 149756 & 7238 & 14674 & 91485 & 16356 & 64274 \\
\hline 2004 & 18190 & b.d. & - & 32782 & - & 8326 & - & - & 18287 & - \\
\hline 2005 & 16869 & 67112 & - & 32172 & 138262 & 8370 & 17413 & - & 15928 & 65420 \\
\hline 2006 & 15363 & 63214 & - & - & 132195 & 6752 & 17095 & - & - & 62594 \\
\hline 2007 & 16191 & 63467 & - & - & 128875 & 6869 & 17805 & - & - & 59230 \\
\hline 2008 & 15669 & 56840 & - & 32831 & 116923 & 6812 & 17647 & - & 16223 & 59891 \\
\hline
\end{tabular}

A dataset in table 12 presents the number of accidents with division into the accidents that occurred on motorways, in and outside built-up area. It should be noted that making any comparisons between the selected countries for the separate years is unfounded. Drawing conclusions on the basis of trends of presented values is more fruitful. In general, in all compared countries most accidents occurred in built-up areas. It is, however, important that on the number of accidents in and outside built-up areas (except for motorways) for all five countries decreasing trend was reported. As for the accidents on motorways, in Poland in the presented period there had been a slight increase in their number, while in Czech Republic it remained moderately stable. In other countries a decreasing trend can be observed. This status may be related to the development of motorway network. During the selected period the most dynamic growth of this road type took place in Poland, taking into account the differences between the beginning and the end of the period (table 13).

\section{Influence of Road Conditions on the Occurrence of Accidents}

Analysis of the causes of road traffic accidents can be run on the basis of the influence of road conditions and the resulting number of fatalities and injuries. By virtue of incomplete data it was possible to present the discussed indicators only for the period $2002-2008$. In table 14 the number of accidents on dry road and other road conditions (wet, icy, etc.) is presented for the compared countries. As it can be seen, in any case the number of accidents on dry road surface, in good driving conditions had been dominant. No danger of driving on dry roads results from this dataset, but rather more cautious approach of road users in case of worse conditions.

Because of incomplete data no analyses in relative terms (e.g. in relation to 1000 accidents) were run. Basing on table 14 and observing the trend of the number of accidents, it is possible to draw general conclusion about road safety improvement in all compared countries, except for Germany, where it was possible to obtain data only for the first two years of the selected period.

\section{Analysis of Road Accidents Considering Different Types of Road}

Analysis of road accidents statistical data with the division of road users into certain groups was run for the period 2002 - 2010, since for the years 2011 and 2012 data were incomplete or, in general, not available.

Having certain indicators expressed in relative terms at disposal (here in relation to 100000 vehicles) it is feasible of course to make comparisons of fatalities and injuries among different road users, such as pedestrians, vehicle drivers and passengers, motorcyclists, cyclists and moped drivers. In table 15 comparison between the number of fatalities, whereas in table 16 - injuries among the users of the selected groups is presented.

In Poland least fatalities were among motorcyclists and moped drivers, since the number of these vehicles are probably relatively smaller than in other countries, while for pedestrians, vehicle drivers and passengers and cyclists relative numbers of fatalities are the largest among selected countries in the same period. This is undoubtedly caused, inter alia, by general status of road infrastructure and non-collision solutions, particularly in urban areas.

The greatest relative value of injuries in the group of pedestrians was observed in the United Kingdom. In Germany there were the most injuries among vehicle drivers and passengers, motor cyclists and cyclists. This is probably due to greater traffic intensity and safer infrastructure (motorways, non-collision solutions), in which injuries dominate over fatalities, which number is limited. For moped drivers it was not possible to develop full comparison in view of the major shortcomings in the available data. 
Table 15. The number of fatalities per 100000 vehicles among the selected groups of road users between 2002 and 2010 for the compared countries.

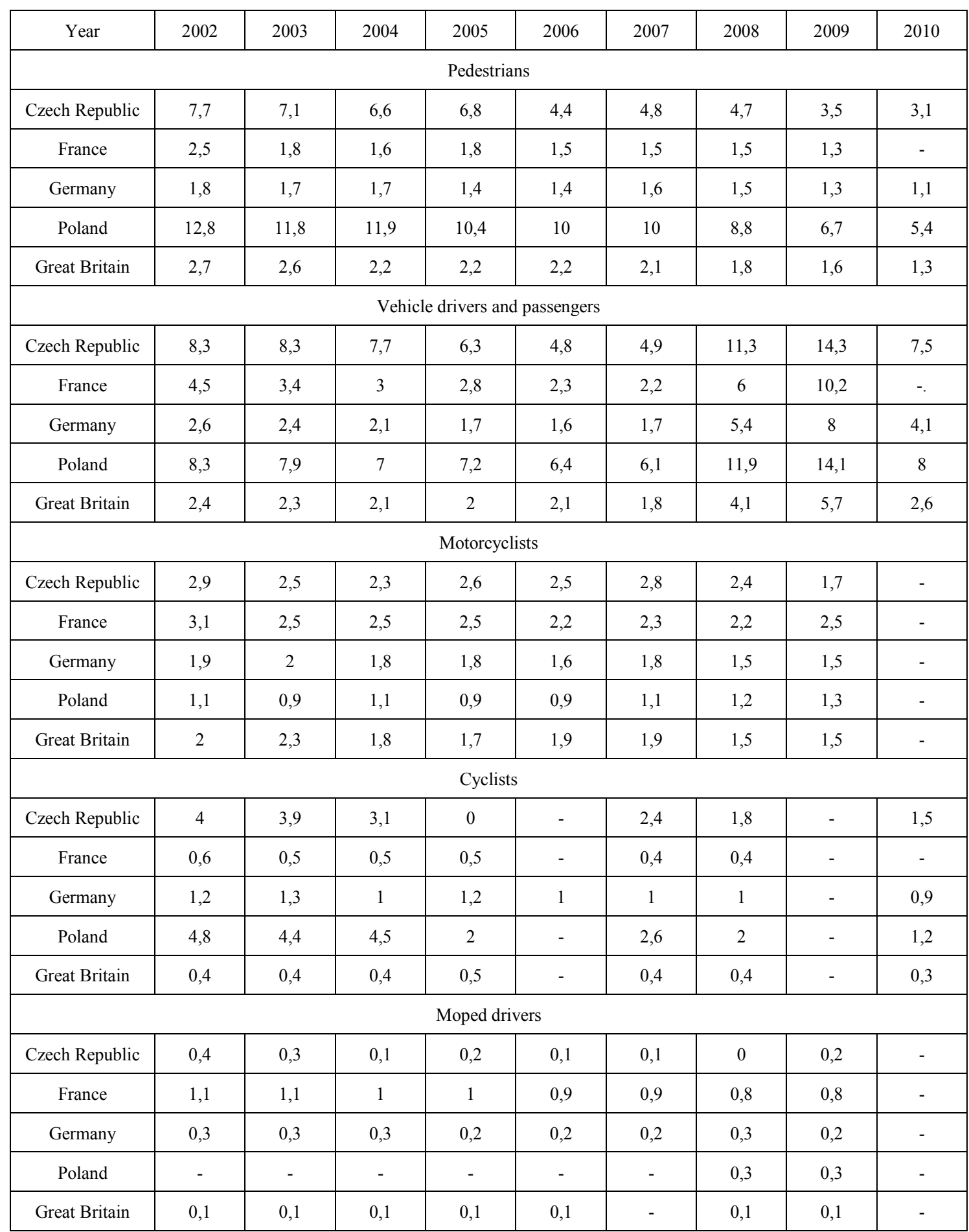

When examining trends of these indicators a decreasing trend can be noted in the group of pedestrians and cyclists and slightly for moped drivers in all countries compared. This status may indicate at least partial separation of such road users from the vehicle traffic. With this may also be associated creation of non-collision passages for pedestrians, as well as cycle paths. 
Table 16. The number of injuries per 100000 vehicles among the selected groups of road users between 2002 and 2010 for the compared countries.

\begin{tabular}{|c|c|c|c|c|c|c|c|c|c|}
\hline Year & 2002 & 2003 & 2004 & 2005 & 2006 & 2007 & 2008 & 2009 & 2010 \\
\hline \multicolumn{10}{|c|}{ Pedestrians } \\
\hline Czech Republic & 124,1 & 111,2 & 107,6 & 94,4 & 85,2 & 82,6 & 75,5 & 71,5 & - \\
\hline France & 46 & 40,2 & 39 & 38,2 & 36,9 & 36,6 & 35 & 33,7 & - \\
\hline Germany & 76,6 & 73,3 & 70,7 & 69,3 & 67,2 & 77,2 & 74,7 & 71,3 & - \\
\hline Poland & 113,7 & 104,3 & 96,1 & 88,3 & 77,8 & 76 & 65,2 & 54,6 & - \\
\hline Great Britain & 129,7 & 119,4 & 110,5 & 103,4 & 99,2 & 94,8 & 88,9 & 84,8 & - \\
\hline \multicolumn{10}{|c|}{ Vehicle drivers and passengers } \\
\hline Czech Republic & 521,7 & 534,2 & 500,1 & 443,2 & - & - & 335,4 & 466,9 & - \\
\hline France & 224,5 & 172,3 & 156,4 & 150,9 & - & - & 110,5 & 211,4 & - \\
\hline Germany & 615,2 & 571,1 & 538,4 & 505,3 & - & - & 512,5 & 824,9 & - \\
\hline Poland & 232,1 & 210,4 & 210,7 & 246,8 & - & - & 164,6 & 199,9 & - \\
\hline Great Britain & 652,8 & 611,6 & 576,4 & 549 & - & - & 477,2 & 630,7 & - \\
\hline \multicolumn{10}{|c|}{ Motorcyclists } \\
\hline Czech Republic & 55,7 & 60,8 & 57,8 & 60 & - & - & 49,1 & 44 & - \\
\hline France & 50,4 & 44,9 & b.d. & b.d. & - & - & 46,2 & 45 & - \\
\hline Germany & 78,7 & 80,2 & 71,5 & 71,2 & - & - & 68,4 & 67 & - \\
\hline Poland & 10,3 & 9,1 & 8,3 & 9 & - & - & 10,6 & 10,4 & - \\
\hline Great Britain & 76,4 & 75 & 79,3 & 75,4 & - & - & 54,2 & 53,8 & - \\
\hline \multicolumn{10}{|c|}{ Cyclists } \\
\hline Czech Republic & 99,6 & 100,8 & 90,6 & 59,8 & - & - & 58 & - & - \\
\hline France & 13,1 & 13,8 & 12,5 & 12,9 & - & - & 12,1 & - & - \\
\hline Germany & 147,9 & 158,3 & 151,7 & 159,1 & - & - & 180,1 & - & - \\
\hline Poland & 49,2 & 47,2 & 42,3 & 17,9 & - & - & 21,1 & - & - \\
\hline Great Britain & 56,6 & 55,5 & 52,3 & 51 & - & - & 50,7 & - & - \\
\hline \multicolumn{10}{|c|}{ Moped drivers } \\
\hline Czech Republic & 4,7 & 4,7 & - & - & - & - & 2,7 & 8 & - \\
\hline France & 48,2 & 46,2 & - & - & - & - & 40,2 & 36,2 & - \\
\hline Germany & 37,7 & 38,1 & 36,8 & 36,3 & - & - & 50,4 & 44,7 & - \\
\hline Poland & - & - & - & - & - & - & 10,4 & 10,1 & - \\
\hline Great Britain & 16,2 & 15,9 & - & - & - & - & 12,4 & 10,6 & - \\
\hline
\end{tabular}

\section{Conclusion}

When analysing statistical data in relative values, a plane for comparisons can be created both for individual years, as well as between different countries. Data in table $1-3$ and $5-7$ show that proper and full analysis can be made with datasets in relative terms, since it is possible to both run comparative analyses, as well as the examination of change in trends of the presented indicators.

It should also be taken into account that collection of so detailed data may involve certain errors due to the ambiguity or discrepancy. For example for one of the colliding vehicles the type of the crash they are involved in may be rear, whereas for the other the front. On one hand accident analysis run by police officers, who would dispose a very exact division of road crash types could lead to 
lengthening the procedures and, on the other, lead authorities to organise training in order to correctly identify and describe the accident scene.

Comparisons and trends identification can be easily made when examining e.g. dynamics of changes of a specified indicator. When disposing complete data an attempt to make overall assessment of road traffic safety in any country is possible, along with determination of possible neuralgic aspects for which deeper analysis is necessary. The results may also be used as a background for further research, e.g. issues related to modelling collisions of a specified type. Analyses showing which tendencies occur in collisions types, which one is the most common and what are their major effects is also possible, which may be background of examination of vehicle collision processes.

Presented data show inconsequence of their collection, due to a large quantity of gaps in full statements. It is therefore essential to introduce a uniform method of road traffic accidents data collection and storage.

The most important in the comparison is having access to both current road accident data and information on planned or implemented activities in road infrastructure or up to date trends in the automotive industry. Such datasets, comparing them by means of appropriate indicators, as well as drawing conclusions from the obtained information may indicate trends of changes and facilitate estimation of close future, when it regards road traffic safety and road accidents. Also segmentation of such factors as the influence of using the same roads by various groups of users allows enrichment the full analysis of more detailed elements.

\section{REFERENCES}

[1] http://statystyka.policja.pl/portal/st/1302/

[2] http://w3.unece.org/pxweb/Dialog/

[3] https://www.destatis.de/DE/Publikationen/StatistischesJahrb uch/StatistischesJahrbuch.html

[4] http://databank.worldbank.org/ddp/home.do

[5] http://www.czso.cz/eng/redakce.nsf/i/home

[6] Kisilowski J., Zalewski J., Chosen problems of road accidents analyses in Poland in the period between 1995 and 2004, Maintenance and Reliability, nr 1 (37)/2008.

[7] Kisilowski J., Zalewski J., Chosen aspects of analysis of road traffic safety in Poland between 1995 and 2008, Journal of KONBIN, No 2,3 $(14,15) 2010$.

[8] Zalewski J., Modelling of the influence of car body disturbances on the stability of motion of road vehicle, Doctoral Thesis, Warsaw University of Technology, 2011.

[9] De Blaeij A., Florax R. J. G. M., Rietveld P., Verhoef E., The value of statistical life in road safety: a meta-analysis, Accident Analysis and Prevention, Vol. 35, Issue 6, Elsevier 2003.

[10] Elvik R., Hoye A., Vaa T., Sorensen M., The Handbook of Road Safety Measures, Second Edition, Emerald Group Publishing Ltd., UK, 2009. 